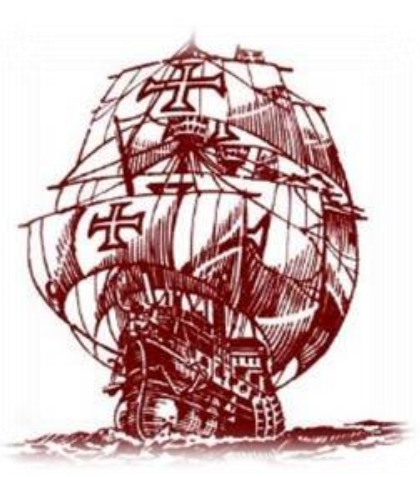

Nau Literária: crítica e teoria de literaturas

www.seer.ufrgs.br/nauliteraria

ISSN 1981-4526 - PPG-LET-UFRGS - Porto Alegre

Vol. 11 N. $01-2015$

100 anos da geração de Orpheu

\title{
A confissão de Sá-Carneiro
}

\section{Estevan Ketzer*}

Resumo: O artigo representa os diferentes contextos que envolveram o suicídio de Mário de Sá-Carneiro em 1916 pela correspondência do autor com Fernando Pessoa. Neste ponto em que o fazer literário esbarra na teoria do absurdo existencial, encontra na morte uma realização e da espetacularização do espírito da belle époque francesa, repleta de possibilidades no campo literário. O tom confessional da literatura de Mário de Sá-Carneiro parece por vezes envolver um eu da narração e um eu próprio da psicologia de modo a que essa convergência expresse uma miríade de deslocamentos simbólicos.

Palavras-chave: literatura; espetáculo; absurdo; belle époque; cartas.

\begin{abstract}
The article represents different contexts that involved Mário de Sá-Carneiro's suicide in 1916 through the mailing with Fernando Pessoa. In this place, where literary production bumps into existential nonsense theory, finds in death an achievement and the spectacle form the French belle époque spirit, full of possibilities in the literary field. The confessional tone from Mario de Sá-Carneiro's literature seems by many times involve a narrative self and a psychology inner self in a way for this convergence to express a myriad of symbolic displacements.
\end{abstract}

Keywords: literature; spectacle; nonsense; belle époque; letters.

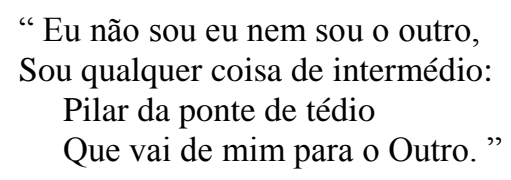

Mário de Sá-Carneiro

\section{Efeitos íntimos}

Olhar pelas letras antes de esquecer o que se vive. Assim um nome conduz que uma carta chega a um destino. Chamam de endereçamento, quando nada mais serve para nos justificar. Temer que esse nome se revele sempre como uma palavra bestial, um nome que não podemos pronunciar para não descobrir a verdade sobre nós mesmos. Estude, pense, mas não

\footnotetext{
* Psicólogo pela Faculdade de Psicologia da PUCRS. Graduando em Ciências Sociais na UFRGS. Mestrando em Teoria da Literatura pela PUCRS.
} 
revele o segredo. Guarde para si essa palavra, pois ela é assim a aura do mais profundo mistério. Imaginar que tudo isso pode estar em um nome é lidar com o desconhecido espaço de trevas, tremores e o abismo mesmo que não ilude sua chegada. Assim ele escrever para seu maior amigo, Fernando Pessoa:

Eu não me mato por coisa nenhuma: eu mato-me porque me coloquei pelas circunstâncias - ou melhor: fui colocado por elas, numa áurea temeridade - numa situação para a qual, a meus olhos, não há uma outra saída. Antes assim. É a única maneira de fazer o que devo fazer. (SÁCARNEIRO, 2004, p. 373)

Era 31 de março de 1916, menos um dia frio em Paris até a aguardada primavera. Está posto o desafio para nosso autor que a todos faz pensar no desalinho da letra e nos festejos da noite, pois se propõe a destruir a si mesmo nessa imolação sem culto de sua atividade epistolar. Como todo o demonstrativo de conhecimento exigindo uma prova de sua durabilidade diante do outro, as cartas não se reduzem a verdades empíricas, achados arqueológicos, ou mesmo a uma constatação da existência do nível subjetivo tão aclamado na dita modernidade. Se o subjetivo nos força pensar tão plenamente naquele que escreve, poderiam as cartas serem uma outra coisa do que a emulsão de seu desejo? A questão aqui levantada poderia ser outra: ao escrever se está a falar de um desejo? E esse desejo pertence realmente ao autor? Mesmo que sua resposta seja conclusiva pelas circunstâncias apofânticas do dualismo ocidental, ainda assim somos exigidos a sentir que as letras preenchem impreterivelmente um espaço em branco.

Será a prosa poética de Sá-Carneiro um modo de falar de si e da criação literária? A morte do autor como nos lembra Barthes (2004a) será também a morte de toda a intencionalidade que um escritor pode ter?

O autor é uma personagem moderna, produzida sem dúvida por nossa sociedade na medida em que, ao sair da Idade Média, com o empirismo inglês, o racionalismo francês e a fé pessoal da Reforma, ela descobriu o prestígio do indivíduo ou, como se diz mais nobremente, da "pessoa humana”. (BARTHES, 2004a, p. 58)

O pensador francês também mostra que neste caráter autoral reside uma espécie de literatura próxima do seu criador e com isso despotencializa o lugar do intérprete fora do lugar da confidência escritural. Contudo, poderíamos não interpretar um documento, seja ele qual for? Falar da subjetividade seria deixar de lado o que a criação mais espontânea aproxima o homem da obra? Os auto-retratos de Van Gogh, nesta perspectiva, poderiam ser encarados como ensaios para alguém que deseja muito profundamente aprender a olhar para si mesmo, com algo além da intensidade de um artista naïf. Tanto Van Goh quanto Sá-Carneiro parecem estar longe de serem artistas que se deixam levar pela ingenuidade e pela pura 
espontaneidade. Suas obras querem falar ainda mesmo que como um esboço fragmentário de si mesmos. Criador, junto de Pessoa e Almada Negreiros da Revista Orpheu, mudando a tônica do pensamento português que a partir de agora mostraria ao mundo um retalho de elementos vanguardistas, embora quando olhamos para o gesto da verdadeira obra de arte, estamos diante de algo que não se deixa arredar por qualquer estilo ou nomeação exclusivista (ADORNO, 2008). Esse fato explora a obra em sua composição, da mesma forma que não se pode ver o inconsciente do autor como um único dispositivo de toda a criação. Ao olharmos profundamente para uma obra de arte, devemos olhar para a lei própria de formação, uma vez que "se lhes acontece integrar sua lei formal imanente" (ADORNO, 2008, p. 20).

Destacamos essa importante ponderação: a carta pode ser vista como obra de arte? Ela surge nesta fenomenologia através de um material que impõe ao sentido uma lógica linguística, como afirma Hamburger (1986). Uma vez empregada dessa forma de interpretação, estamos diante do pensamento e seu transbordamento diante de si mesmo, isto é, aquilo que ele começa a organizar, para buscar o sentido, mesmo que na sua mais ampla e desregrada forma. Uma obra de arte toca os sentidos, talvez mais a fundo, toque os sentires que dizem respeito ao sentido. As cartas nos aproximam à vida, mas não apenas de quem faz a arte, mas à vida do próprio intérprete, essa é a nova e refundamentar a tese da morte do autor:

Nada mais deprimente do que imaginar o Texto como um objeto intelectual (de reflexão, de análise, de comparação, de reflexo etc.). O Texto é um objeto de prazer. (...) quando o texto "literário" (o Livro) transmigra para dentro de nossa vida, quando outra escritura (a escritura do Outro) chega a escrever fragmentos da nossa própria cotidianidade, enfim, quando se produz uma co-existência. (BARTHES, 2005, p. XIV-XV)

Sá-Carneiro parece estar muito próximo de nossas vidas, não por nos fazer alegres, mas por nos entristecer, como apresenta em carta de 16 de novembro de 1912:

Vê Você, eu sofro porque sinto próxima a hora em que o recreio vai acabar, em que é forçoso entrar para as aulas. Talvez não me compreenda nestas palavras, mas eu não tenho paciência nem força para lhe falar mais detalhadamente: Em suma não creio em mim, nem no meu curso, nem no meu futuro. Já tomei várias decisões desde que aqui estou e um dia senti, na verdade senti cheio de orgulho, que me chegara finalmente a força necessária para desaparecer. Ilusão dourada! Na manhã seguinte essa força remediável tinha desaparecido. E então resolvi voltar à Lisboa, sepultar dentro de mim ambições e orgulhos. Mas não tive também força para o fazer. Sorria-me Paris e, lá ao longe, um fiozinho de esperança que todas as aspirações dentro de mim me fizeram ver como um facho resplandecente. (SÁ-CARNEIRO, 2004, p. 37)

Desaparecer para dar luz a algo que seja consumido pelo fogo da existência. Chegar a essa arte que a vida sempre leva a uma nova pista de sua formação, como encontramos no poema 7, apresentado na Revista Orpheu, em 1915. "Eu não sou eu nem sou o outro, / Sou qualquer coisa de intermédio: / Pilar da ponte de tédio / Que vai de mim para o Outro." (SÁ- 
CARNEIRO, 2015, s/n) Tédio esse que na fenomenologia não escapamos de compreender o cansaço do suicida. "Depois, coisa interessante, quando eu medito horas no suicídio, o que trago disso é um doloroso pesar de ter de morrer forçosamente um dia mesmo que não me suicide. " (SÁ-CARNEIRO, 2004, p. 41).

Estamos diante de uma literatura que margeia o absurdo, como Camus (2010) nos implica a pensar. Sá-Carneiro vê no suicídio a saída para suas dificuldades, enquanto Camus nos mostra que é o pior jeito de lidar com o absurdo. A busca lhe é incompatível, mas continua mesmo assim a gozar da noite parisiense. Ao pensar o suicídio como tragédia é a consciência que remete a si mesma no ato de divórcio da vida (CAMUS, 2004). É nesse exagero do eu que Sá-Carneiro opera suas cartas, enviando ao amigo Pessoa, além de toda a crítica possível, o elemento confessional, parte de si a ser explorada de si, parte dessa impossível medida que se chama o $E u$. Aqui está nosso dilema científico-literário: diferentemente do método antropológico, a literatura não o faz com interesse de representar a realidade, mas opera junto a esta para formular o estilo. No caso, o absurdo causa espanto, somos incapazes de compreendê-lo sem antes deixarmos um estilo significativo de fora. Precisamos nessa empresa libertar o estilo-estigma do realismo para enxergar a arte em expansão.

O poeta português o faz como poucos na exigência que seu amigo Pessoa escreva o quanto antes e lhe remunere com a venda de seus livros. É na carta de 16 de novembro de 1912 que aparecem os primeiros indícios do absurdo representado pelo suicídio, cuja angústia insurge nos bastiões de todo o princípio de afetividade. Os amedrontamentos tomam forma pela primeira vez em seus escritos: "E sofro ainda também, meu querido amigo, por coisas mais estranhas e requintadas - pelas coisas que não foram. " (SÁ-CARNEIRO, 2004, p. 37). Que coisas são essas? Será uma vida de infelicidade profunda que passa por seus olhos sem ele fazer nada mais além de sua empresa missivista? Profunda melancolia temperada no esforço contínuo da escrita. A última fronteira não está mais na descoberta da Índia, mas na libertação que a poética traz.

Para Foucault (1992, p. 151) a carta faz parte de uma espécie de arte de si, ela presentifica o autor e aponta ainda um desvelamento da alma. "Por meio da missiva, abrimonos ao olhar dos outros e instalamos o nosso correspondente no lugar do deus interior. "Será a carta uma forma de assassinar deus? Olhar para dentro de nós será tão danoso como se imagina? Estranha decifração que o olhar deixa escapar. “(...) cada um de nós será para o outro o socorro permanente" (FOUCAULT, 1992, 149). O que também nos apresenta a incapacidade de um olhar conclusivo acerca da alteridade. Assim como a poesia lírica nos 
propõe a gentileza do som, devemos ler Sá-Carneiro ouvindo seu canto enlutado, tomando conta de uma fragilidade solapante e desconhecida.

\title{
2 Construção poética no tempo e espaço
}

\begin{abstract}
Um artista busca a perfeição - é esta a sua tortura máxima - e desfaz e refaz sua obra. Vence: atinge a perfeição e continua a ansiar [?] fazer maior: porém a tela em que trabalha evola-se por fim, dilui-se, torna-se espírito, desaparece. Esse artista ultrapassa a perfeição. É possível que em vez dum pintor faça dele um músico. (SÁ-CARNEIRO, 2004, p. 52)
\end{abstract}

O autor português é antes de tudo um precursor de uma arte extremamente marcante, relacionada ao conflito autobiográfico. Conflito esse estudado por Philippe Lejeune (2008) no qual a poética assume a função de ficção. A psicanálise nos mostra o quanto o gesto biográfico não tem como ser verdadeiro, no sentido empirista da ciência positivista. Certamente não estamos a falar de um método novo, mas sim na deficiência em falar sobre nós como sujeitos que propõe um saber. Mesmo tendo esta crença inicial, o fazemos com enorme fidedignidade, preenchemos os campos vazios do desconhecido como os florilégios da poética, para assim fazermos da palavra a nossa morada. Mesmo uma poética da autodestruição parece mencionar que todo o resto é complemento ao conteúdo.

Um psicanalista, por melhor que seja, não acerta o tempo todo, pois faz uso da linguagem poética para ilustrar sensações internas correntes. Pelo contrário, para acertar deve antes poder errar, tornar-se consciente de que a palavra autobiográfica é uma tentativa parcial para uma descrição total. "Quantas vezes em frente dum espelho - e isto em criança - eu não perguntava olhando a minha imagem: 'Mas o que é ser-se eu; o que sou eu? '. E sempre, nestas ocasiões, de súbito me desconheci, não acreditando que eu fosse eu, tendo a sensação de sair de mim próprio. Concebe isto?" (SÁ-CARNEIRO, 2004, p. 63)

Esse instante tão óbvio e ao mesmo tempo tão inquietante. Não será esse questionamento que coloca o filósofo tão perto do escritor? Parece que a tudo se pode saber, ou ao menos ter a pretensão de vir a saber. Palavra devir tão preconizada pelo paradigma nietzschiano, tão caro à filosofia da sombra na aurora da segunda metade do século XX. Nesse momento, a criação da belle époque francesa nos remete a grande festa do agir poético sensacional, esboçada na Revista Orpheu. Em A confissão de Lúcio, Mário de Sá-Carneiro, exalta esse processo de escrita:

De forma que a luz total era uma projeção da própria luz - em outra luz, seguramente, mas a verdade é que a maravilha que nos iluminava nos não parecia luz. Afigurava-se-nos qualquer 
outra coisa - um fluido novo. Não divago, descrevo apenas uma sensação real: essa luz nós sentíamo-la mais do que a víamos. (SÁ-CARNEIRO, 1993, p. 33)

Isso também nos lembra de que as cartas são partes de uma complexidade tanto autoral quanto simbólica. Os sentidos que Fernando Pessoa tentara encontrar em uma objetividade linguística aqui se imiscuem em uma indagação sempre incompleta. Mundo, finitude, horizonte do homem diante de si num desenrolar de ideias que no horizonte do real não alcança. Essa dependência de que o Real nos acomodaria, aplainando as arestas da subjetividade para massificar e educar os cinco sentidos. Seria a isto que a filosofia existencial se dirige? Camus (2010) olha de dentro da gaiola de ferro da existência. Somente ao sermos diante do mundo somos conduzidos a uma opção por nossa vida.

Vivemos no futuro: "amanhã", "mais tarde", "quando você conseguir uma posição", "com o tempo vai entender. " Estas inconseqüências são admiráveis, porque afinal trata-se de morrer (...). O amanhã, ele ansiava o amanhã, quando tudo em si deveria rejeitá-lo. Essa revolta da carne é o absurdo. (CAMUS, 2010, p. 27)

O mundo não escapa por ser denso demais para penetrá-lo, exige clareza, silêncio, familiaridade, para mantermos a conformidade com as regras sociais do dizer, do ver e do pensar. Consciência bem conformada é tudo o que arte não suporta mais. Inexata medida entre palavra, psicologia e estranhamento com o mundo das noções exatas. Não somos um cálculo previsível, nem militares que seguem ordens com efetividade. A escrita se não nos faz convergir para esse inteiro do conjunto que nossa mente dita como realidade conjugada, levanos a um novo espanto existencial: não pode estar no grau zero, como um estilo jornalístico, escrita da ausência de todo o signo livre do sentido, ou o escritor sem Literatura.

Se a escrita for realmente neutra, se a linguagem, em lugar de ser um ato embaraçoso e indomável, chegar ao estado de uma equação pura, não tendo mais espessura do que uma álgebra e face do vazio do homem, então a Literatura está vencida, a problemática humana está descoberta e entregue sem cor, o escritor é, sem volta, um homem de bem. (BARTHES, 2004b, p. 67)

A escrita deve nascer da indefinição, o que gera a boa escrita, como salienta Barthes. “(...) o poeta manuseia o mistério, interroga o além”, como Sá-Carneiro (2004, p.112) pontua um texto de Fernando Pessoa na correspondência de 3 de fevereiro de 1913. Nesta poética das sensações é o artista que está a realizar intenções, como fica nítido em Dispersão, enviado para Pessoa antes da publicação editorial.

\footnotetext{
Perdi-me dentro de mim

Porque eu era labirinto,

E hoje, quando me sinto,

É com saudades de mim.

(...)

Perdi a morte e a vida,
} 


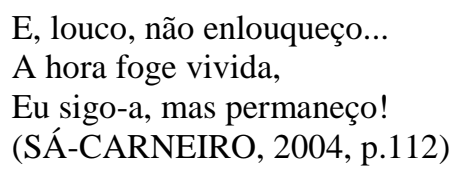

Esse misto de verdade e ficção que nos aparece como a descoberta do preço a pagar para se fazer literatura no século XX, será também a necessidade de que um autor possa ser com a escrita de cartas ele mesmo um pouco... "Quando estou só, eu não estou só mas, nesse presente, já volto a mim mesmo sob a forma de Alguém. Alguém está aí, onde estou só. " (BLANCHOT, 2011, p.23) Como viver esse Alguém? Essa experiência de vivência que como uma dobra da mônada de Leibniz parece a uma ausência do ser, uma falta que me origina. "Escrever é quebrar o vínculo que une a palavra ao eu" (BLANCHOT, 2011, p. 17). Escrever é não terminar, é deixar que o outro fale quando eu substituo o eu por outro e isso provoca o silêncio. Será que o autor Sá-Carneiro cria um narrador para explorar o mundo da arte de um jeito diferente? Haverá temor ao vivenciar o silêncio?

Não podemos esquecer que a belle époque é toda permeada de uma arte simbólica, alusiva, um convite a um avanço na meditação do mundo e ao mesmo tempo celebração ao ruído e o acontecimento espontâneo. Entre o passado ou o presente, neles habitam sentidos de um social em ebulição e a juventude começa a usar o ópio para buscar esse silêncio desconhecido. Mais entranhado resgate de uma imagem que dela não sabemos nos desprender, como aparece com a chegada da fotografia e sua possível suplementação da pintura. Será Baudelaire (apud BENJAMIN, 1996) quem farpa a denúncia da pintura como necessária ida ao inédito que a representação fotográfica impõe à sacralidade do ver. $\mathrm{Na}$ ignorância das massas, há a segurança de uma naturalização do olhar e sua função de encontro. Somente o choque é literal, no sentido de propor o inédito a saída do signo. O espectador fica paralisado em sua percepção de que contempla e apreende a realidade, responde-nos Benjamin. Igualmente, vemos tais efeitos na espetacularização da sociedade, como Debord (1997) denuncia.

\footnotetext{
Não é de estranhar que, desde pequenos, os alunos comecem, com grande entusiasmo, pelo Saber Absoluto da informática: enquanto isso, ignoram cada vez mais a leitura, que exige um verdadeiro juízo a cada linha e é a única capaz de dar acesso à vasta experiência humana antiespetacular. A conversação já está quase extinta, e em breve também estarão mortos muitos dos que sabiam falar. (DEBORD, 1997, p. 189)
}

São os efeitos do espetáculo como um fantasma a nos assombrar, através dessa exigência de mudança ininterrupta para não observarmos nossos motivos pessoais envolvidos. Alienação em outras palavras, mas dessa vez com efeitos auto-reguladores. Tal efeito de mímese faz perder toda a mobilidade da existência em direção a um movimento que a 
experiência não dá conta. Assim, Beatriz Sarlo (2007) aproxima a incidência de uma trágica narrativa, envolvendo essa dimensão de assombração. As experiências desordenadas se dirigem ao desconhecido de nós, são traumáticas, irreversíveis. Quando começamos a pensar, estamos nos envolvendo com a dúvida apodítica que baliza nossa existência firmada na segurança do saber.

Os relatos testemunhais são "discurso" nesse sentido, porque tem como condição um narrador implicado nos fatos, que não persegue uma verdade externa no momento em que ela é enunciada. É inevitável a marca do presente no ato de narrar o passado, justamente porque, no discurso o presente tem uma hegemonia reconhecida como inevitável e os tempos verbais do passado não ficam livres de uma "experiência fenomenológica" do tempo presente da enunciação. (SARLO, 2007, p. 49)

Será, então, Sá-Carneiro um homem implicado em sua vida assim como implicado em sua arte? Parece que o tempo todo ele tenta fazer de suas cartas, registros desses atos confusos e pessoais, como uma escrita de um blog na internet, intuindo uma possibilidade já pósmoderna de traumatizar o eu pela necessidade narcísica de sobrevivência. Narciso vive em algo que não é patologia o tempo todo, mas sua insistência e repetição aparecem como o princípio de uma negatividade e repetição, como um ensaio ainda em construção, um material tão imbuído de técnica que se torna novamente testamento, trauma e legado para o futuro.

\section{História e enigma}

Hoje sou embalsamamento de mim próprio. Não tenho estados de alma, nem os posso ter já porque dentro de mim há algodão em rama (o algodão em rama há dentro de animais naturalizados) ... Estados da alma, ânsias, tristezas, ideais, grandes torturas de que saíam os meus livros tudo isso acabou... Ilusões de glória, de "espanto" já não existem em mim. Entusiasmos do que eu sou, tão pouco, porque demais sei o que sou. Sou o que quero - o que queria Ser; mas sei que não sou. Logo... (SÁ-CARNEIRO, 2004, p. 187)

Escreve em carta datada de 13 de julho de 1914 que sua vida falta para ele. Paralisia do bálsamo que não conseguem mais utilizar a forma criativa. Mas seria aqui também o mais recôndito dos lugares para expressar sua criatividade? Mesmo tão próximo da aniquilação, SáCarneiro se deixaria conduzir pelo passo demarcado da epístola. Ele sabe o quanto é forte a debilidade que se acentua enquanto suas festas e jogos o levam à ruína financeira. Os pedidos para que Pessoa venda suas obras e lhe envie o dinheiro pelo correio se tornam constantes, já que seu o pai teve de rumar para a África para pagar as contas do filho. O sistema monetário, o prazer e a falência do corpo, tudo isso é ainda uma equação que não permite saída. A vida que o autor escreve leva a um desaparecimento iminente. 
Na passagem de 30 de setembro de 1915, fala de sua paupérrima situação financeira: "Não morria, claro: o dinheiro do meu Pai chega o mais tardar a 18 e sempre poderei pedir 10 francos a alguém e pôr por 9 o relógio no prego, vivendo assim os 4 dias. Mas compreende bem como isso é desagradável. " (SÁ-CARNEIRO, 2004, p. 189). Na correspondência de Pessoa para o amigo interlocutor, já percebemos que se abatem também impressões de que algo o perturbara profundamente. O mistério de certos segredos ocultistas começa a apavorálo. Realidade de um além que não seria loucura, por suas palavras, mas um desconhecido que quando bate a porta o paralisa por completo.

Sá-Carneiro suplica ao amigo que não demore a lhe retornar. Pessoa entra em longos períodos de silêncio para se adentrar em sua psicologia mais interna. Em carta de 18 de fevereiro de 1916, Sá-Carneiro fica reticente em enviar telegrama ao pai, por necessitar de 1000 francos. "Não lhe dizia que estava doido? Vivo há semanas num inferno sem nome" (SÁ-CARNEIRO, 2004, p. 361). O poeta lisboeta dá indícios, cuja obra está a se realizar em si próprio, uma vez que toda a criação parece rumar para esta inquietação eterna de sua vida.

\begin{abstract}
A aumentar tudo isto a inconstância sempre duma situação e dum futuro: suponha você que o meu Pai casou com a pessoa que o meu amigo sabe e a tem, desde Dezembro, em Lourenço Marques. Porém a casa da P. dos Restauradores existe da mesma maneira, vivendo lá a minha Ama e os gatos e uma criada. Tudo isto porém há de ter um fim - e eu pergunto-me que lugar irei preencher nesse fim. (SÁ-CARNEIRO, 2004, p. 363)
\end{abstract}

Ruim convivência que o pai propõe ao autor, para que viva lá com ele e com a antiga ama, Maria Cardoso - apelidada Mimi - e a qual se imagina um certo mal-estar na convivência com ela. "Você compreende bem o despenhadeiro que seria para mim esta solução - não é propriamente L. Marques o pavor: mas a convivência que eu aí iria ter - e a à qual me receio muito condenado." (SÁ-CARNEIRO, 2004, p. 363) Maria Estela Guedes (2011) aponta que a convivência com Mimi não era boa, mas ficam as dúvidas se não era boa porque ele também se sentia encantado por ela, como aponta a comentadora e editora de suas cartas, Teresa Sobral Cunha, ao explicar a carta de 22 de fevereiros de 1916. "Sá-Carneiro teve grande proximidade, por quem parece ter tido desvelos do tipo amoroso e a quem endereçou algumas cartas e dezenas de postais revelados há alguns anos" (CUNHA, 2004, p. 453)

Logo, um gesto suicida irrompe a sensação neurótica de perda da realidade e da arte que criava sua vida, arte essa que só existe agora na entrega da amizade definitiva com Pessoa, mas nessa inteira e incompleta via epistolar. A história do poeta é seu maior segredo, ansiedade e forma. Para se fazer arte no século XX, ela terá de ser uma cápsula e deslocar a vida por completo, como uma rica experiência laboratorial, é com o último lampejo de vida 
que a arte mais rica irá nascer. $\mathrm{O}$ experimento deve nascer desse contato com o inesperado, o gesto que a máquina não computa facilmente. É justamente pela apropriação dessa máquina capitalista que a arte introduz esse embaraço, entre o momento de dar como certo aquilo que, mais do que nenhum, o surrealismo tocou bem mansamente, tirando dos objetos suas formas neuróticas nominais, atribuindo um sentido ao non sense. Observamos o sintoma da morte da filosofia pelas mãos da literatura. É o que expressa a carta de 16 de novembro de 1912 :

Já tomei várias decisões desde que aqui estou e um dia senti, na verdade senti cheio de orgulho, que me chegara finalmente a força necessária para desaparecer. Ilusão dourada! Na manhã seguinte essa força remediável tinha desaparecido. E então resolvi voltar para Lisboa, sepultar ambições e orgulhos. Mas não tive também força para o fazer. Sorria-me Paris e, lá ao longe, um fiozinho de esperança que todas as aspirações dentro de mim me fizeram ver como um facho resplandecente. (SÁ-CARNEIRO, 2004, p. 37).

O narrador de A Confissão de Lúcio vive seu labirinto lascivo, no excesso de um borramento de si. "Mistério... O certo é que ao possuí-la eu era todo medo - medo inquieto e agonia: agonia de ascensão, medo raiado de azul; entanto morte e pavor" (SÁ-CARNEIRO, 1993, p. 86). É o mistério de todo o desejo que não se move de si, vive no gozo, na submissão de que esse candente raiar não tenha onde iluminar, senão em outro vão de absurdo. É como se o narrador estivesse a cometer incesto, esbarrando na proibição mais desejada e ainda assim continuasse inconsequentemente. "Enlaçava-me agora sobre o seu corpo nu, como quem se arremessasse de um abismo encapelado de sombra, tilintante de fogo e gumes de punhais - ou como quem bebesse um veneno sutil de maldição eterna, por uma taça de ouro, heráldica, ancestral...” (SÁ-CARNEIRO, 1993, p. 87). Ele, narrador, passa a estranhar a vida, passa a buscar uma narrativa que suporte essa tênue linha entre a loucura e a sanidade, muito comum no imaginário do final do século XIX.

Um minuto de silêncio antes do próximo gole de vinho. O homem que aí passa deixa de sorrir ao amanhecer. É muito fácil perder, mas o jogo é assim mesmo. Época que grita porta abaixo. Sá-Carneiro compartilha com o mundo sua angústia criativa. Situação sobre o seu lugar no mundo, tal como Hamburger nos sugere que uma carta é um texto com um certo sujeito histórico:

Levantamos ainda a alegação, (...), de que as coisas e fenômenos naturais descritos nestas sentenças "realmente" existem e foram assim, por terem sido descritos numa carta identificada como autêntica e por descrevê-los o autor da carta não como uma fantasia ou um sonho, mas como algo "realmente" experimentado e visto assim. (HAMBURGER, 1975, p. 29)

O sujeito que expressa existe, por ele passam as impressões de um universo de significações, mas ele existe. Para a Literatura, a veracidade é inegável, mas a noção do que seja real é que pode ser discutida acerca da autonomia dos objetos pensados, permitindo que 
indaguemos o tempo e o caráter da enunciação. A realidade externa que se quer captar passa a ser a relação espaço-tempo, já pensadas por Kant como fundadoras da atividade cognoscente.

Eis que no da 31 de março de 1916, o Sr. Sá-Carneiro surpreende com força: "Eu não me mato por coisa nenhuma: eu mato-me porque me coloquei pelas circunstâncias - ou melhor: fui colocado por elas, numa áurea temeridade - numa situação para a qual, a meus olhos, não há uma outra saída. Antes assim. É a única maneira de fazer o que devo fazer." (SÁ-CARNEIRO, 2004, p. 373)

Talvez as razões fiquem mais claras no parágrafo seguinte:

\begin{abstract}
Contava com certa soma que pedira ao meu Pai há 15 dias. Ela não chegou - e como resposta um telegrama à legação em que o meu Pai pergunta quanto dinheiro preciso eu para ir para Lisboa.... Houve decerto um mal-entendido, ou falta de recepção dum meu longo telegrama expedido em 19. Segunda-feira preciso inadiavelmente de 500 francos. Como a menos dum milagre eles não podem chegar... aí tem o meu Amigo. (...). Hoje vou viver o meu último dia feliz. Estou muito contente. Mil anos me separam de amanhã. Só me espanta, em face de mim, a tranqüilidade das coisas... que vejo mais nítidas, em mais determinados relevos porque as devo deixar brevemente. Mas não façamos literatura. (SÁ-CARNEIRO, 2004, p. 374)
\end{abstract}

Não, não temos espaço para ela quando a morte está a bater, bater forte como a quinta sinfonia de Beethoven representa tão bem. Mas não será um pedido de socorro ao amigo? Somente no dia 17 de abril, temos carta nova missiva endereçada a Paris. Entre esses dias transcorridos, muitas ameaças de se atirar para debaixo do metrô na estação Pigalle. Seu pai nada pode fazer para salvar-lhe, não lhe enviará o dinheiro que precisa. Mas é na carta de José Araujo endereçada ao amigo Fernando Pessoa que se esclarecem muitas coisas dessa história:

Um dia, 26 entrou ele no meu escritório como costumava, depois de falarmos uns momentos disse-me - Araújo preciso que você vá hoje a minha casa às $8 \mathrm{~h}$, em ponto, sem falta. Assim fiz, quando entrei no quarto, notei que ele estava deitado, muito naturalmente perguntei se lhe doía a cabeça; foi então que ele disse - acabei agora de tomar cinco frascos de arseniato de estricnina, peço-lhe que fique - corri logo abaixo a buscar um copo de leite, ao mesmo tempo dizia ao criado para subir com o mesmo, enquanto eu ia ao comissariado procurar um médico e ao mesmo tempo um automóvel para o conduzir a um hospital, tudo isto tinha sido feito rapidamente, quando subi com os dois agentes para o transportar ao automóvel, foi então que presenciei a cousa mais horrível que se pode imaginar. Sá-Carneiro agonizava, congestionado numa ânsia horrível, todo contorcido, as mãos enclavinhadas, momentos depois expirava; nada havia que o salvasse, eram 8 horas e 20 minutos, depois foi o quarto fechado por ordem dos agentes e eu fui ao comissariado prestar esclarecimentos. Às 11 horas entrámos novamente no quarto, o comissário dois agentes e eu. Sobre a mesa bem à vista estava uma carta para mim, mais atrás nova carta para o Pai, outra para o meu amigo, e mais duas, uma para a tal rapariga, outra para Carlos Ferreira. Sobre o fogão uma folha de papel na qual escrito a lápis e em francês estava o seguinte. Declaro que mato voluntariamente peço p: assim (mim?) o cumulado (?), e para dar a cigarreira ao meu amigo Araújo como recordação, havia também espalhados sobre a mesa 5 frascos vazios de arseniato de estricnina, comprados em diversas farmácias. A rigidez cadavérica foi logo, momentos, digo uns 3/4 horas depois, estava vestido, penteado; horrível, os olhos muito fora das órbitas, a boca aberta, as mãos fechadas sobre o ventre, as pernas um pouco abertas, logo depois da morte tomou uma cor esverdeada que se acentuou pouco a pouco. Depois de revistado por um policia só foram encontradas duas moedas de 10 cêntimos no bolso do colete. Depois de todas estas coisas a que tive a coragem de assistir, foi a porta novamente fechada. No comissariado tomei a responsabilidade sobre o enterro pois o 
pobre amigo como sabe só aqui tinha eu e Carlos Ferreira como mais íntimos. Fui a casa de Carlos Ferreira e dei-lhe conta do sucedido eram meia-noite ou 1 hora não me recordo. (ARAÚJO, 2011, s/p)

Fatos que envolvem o discurso na via de um imaginário que perde a realidade ao tentar alcançá-la. Ao continuar a leitura da carta, surge novo elemento para esse emaranhado jogo de sentidos. O dia 26 de abril de 1916 chega, simplesmente como um dia, em que: "Morre jovem o que os Deuses amam", conforme nos escreve Fernando Pessoa (1988, p. 157) em homenagem ao amigo. É ele quem também escreverá que Sá-Carneiro foi suicidado por seus compatriotas portugueses, tendo sua arte rejeitada (PESSOA, citado em SÁ-CARNEIRO, 2004, p. 403). É o que escreve Pessoa ao saber da morte do amigo:

Ele fez o que todo o artista devia fazer em Portugal. É preciso muita fé no futuro para poder sentir-se compatriota destes sub-homens, para poder saber-se português e não se matar ou morrer.

A maioria de nós morre lentamente, suicida-se pela vida, mata-se quotidianamente, saciado do nojo de gozar o nojo de ter nascido em Portugal!

Tudo quanto é mau manda, tudo quanto é medíocre triunfa.

Esta pátria podre não tem por onde se ame. Só o conceito de uma pátria melhor pode dar a sombra de um alento a uma dolorosa alma contemporânea.

Sim, mesmo neste feudo abjecto de Inglaterra houve algumas recordações incarnadas de tempos em que a Europa chegou até aqui.

No fundo, para o português, há só uma tragédia - que a de ser português.

Quaisquer que fossem, para ele próprio, as razões aparentes do seu suicídio, esta foi a razão primacial. O absurdo de ser uma alma de artista e ter nascido português é uma falha sem solução

Aqui a convergência tão sutil parece se realizar nessa emergência entre o Eu biográfico e o Eu literário. Isso já não é suficiente para que o Eu, uma vez tendo criado uma ficção de si mesmo, seja ele uma realidade imaginada para si mesmo? Viver as emoções é somente o que acreditamos viver dentro de nós? Absurdo que nos faz carregar a pedra de Sísifo como alternativa ao absurdo de manter a vida no limiar das certezas.

\section{Conclusões}

Tentamos mostrar que uma emoção literária é algo que excede o Eu biográfico, mas depende dele para trilhar essa jornada. Há um novo tipo de herói, tão pessoal quanto um blog de internet, que pode assegurar confiança ou mesmo reduzir a discussão para uma parcialidade, e isso seria o fim da obra de arte. Sá-Carneiro, em sua atividade experimental, deixa rastros de que perseguia a morte não apenas pelo desespero existencial, mas como a nova obra que o século XX chamará de happening, acontecimento único e instante de alcance máximo do êxtase. Ele esperava algo de Pessoa, uma correspondência que se cerca de 
expectativas e se dirige a um contato de alteridade sem origem, mas com as emoções sempre em um constante trabalho. Fernando Pessoa, retraído como era característica sua, não continuou o diálogo. $\mathrm{O}$ que resta desse contato é um bilhete em folha de mimeógrafo - tão utilizada na França - de Sá-Carneiro para o grande o seu amigo cheio de heterônimos e atarefado com seus sofreres. É o seu último registro endereçado ao amigo, sem qualquer outra explicação, como a morte que sempre vem repentina e simples, a desfazer os laços dos homens com o mundo:

$$
\begin{aligned}
& \text { Um grande, grande } \\
& \text { adeus do seu pobre } \\
& \text { Mário de Sá-Carneiro } \\
& 16 \text { de abril } 1916
\end{aligned}
$$

\section{REFERÊNCIAS}

ADORNO, T. W. Teoria Estética. Lisboa: Edições 70, 2008.

ARAUJO, José. Carta à Fernando Pessoa acerca da morte de Mário de Sá-Carneiro. Disponível em: 〈http://www.pessoa.art.br/?p=284〉. Acesso em: 24 jun. 2011.

BARTHES, Roland. A morte do autor. In: O rumor da língua. São Paulo: Martins Fontes, 2004a.

. O grau zero da escrita. São Paulo: Martins Fontes, 2004b.

. Sade, Fourier, Loyola. São Paulo: Martins Fontes, 2005.

BENJAMIN, Walter. Magia e Técnica, Arte e Política: ensaios sobre literatura e história da cultura. São Paulo: Editora Brasiliense, 1996, vol. 1

BLANCHOT, Maurice. O espaço literário. Rio de Janeiro: Rocco, 2011.

CAMUS, Albert. O Mito de Sísifo: ensaio sobre o absurdo. Rio de Janeiro: Best Bolso, 2010.

DEBORD, Guy. A sociedade do espetáculo. Rio de Janeiro: Contraponto, 1997.

FOUCAULT, Michel. O que é um autor? Lisboa: Vega/Passagens, 1992.

HAMBURGER, Käte. A Lógica da Criação Literária. São Paulo: Perspectiva, 1975.

LEJEUNE, Philippe. O pacto autobiográfico: de Russeau à Internet. Belo Horizonte: Editora UFMG, 2008.

PESSOA, Fernando. O Banqueiro Anarquista e outras prosas. São Paulo: Círculo do Livro/Cultrix, 1988 
SÁ-CARNEIRO, Mário de. Correspondência com Fernando Pessoa. (Ed. Teresa Sobral Cunha). Rio de Janeiro: Companhia das Letras, 2004.

. A Confissão de Lúcio. São Paulo: Editora Núcleo, 1993.

. 7. In: Luís de Montalvor; Mário de Sá-Carneiro; Ronald de Carvalho; Fernando António Nogueira Pessoa; José Sobral de Almada Negreiros. (Orgs.). Revista Orpheu $N^{o} 1$. Disponível em: http://www.gutenberg.org/cache/epub/23620/pg23620.html. Acesso em: 15 mar. 2015.

SARLO, Beatriz. Tempo Passado: cultura da memória e guinada subjetiva. São Paulo: Companhia das Letras/Editora UFMG, 2005. 